\title{
Prevalensi Anemia Defisiensi Besi pada Bayi Usia 4 - 12 Bulan di Kecamatan Matraman dan Sekitarnya, Jakarta Timur
}

\author{
${ }^{*}$ Rini Sekartini, *Soedjatmiko, **Corry Wawolumaya, *Irene Yuniar, *Rismala Dewi, *** Nycane, \\ *** Imam $D,{ }^{* * *} \operatorname{Imam} N,{ }^{* * *}$ Adam
}

\begin{abstract}
Latar belakang: prevalensi anemia defisiensi besi masih tinggi terutama pada bayi. Deteksi dini terhadap anemia pada bayi terutama bayi dengan risiko tinggi sangat diperlukan untuk mencapai tumbuh kembang optimal.

Tujuan: untuk mengetahui prevalensi anemia defisiensi besi.

Bahan dan cara metode: studi deskriptif belah lintang dilakukan di empat Puskesmas di Jakarta Timur. Populasi sampel adalah bayi umur 4-12 bulan yang tinggal di wilayah Kecamatan Matraman dan sekitarnya pada bulan Maret 2004. Sampling diambil dengan metode convenient, pengumpulan data dengan pengisian kuesioner oleh ibu bayi secara terpimpin. Pengukuran di lakukan pada panjang badan, berat badan, lingkar kepala bayi. Pemeriksaan kadar hemoglobin menggunakan Hemocue ${ }^{\circledR}$, sedangkan serum feritin diperiksa di laboratorium SEAMEO-TROPMED FKUI.

Hasil: sampel terdiri dari 55 bayi, 63,6\% laki-laki, 58,2\% berumur 8-12 bulan, dan $87,3 \%$ berasal dari keluarga dengan pendapatan per kapita per bulan rendah. Sebagian besar berstatus gizi kurang (60\%), 96,4\% lahir cukup bulan, 3,6\% bayi lahir dengan berat badan rendah pemberian ASI ekslusif 94,5\%. Diantara 55 bayi 38,2\% mengalami anemia dan $71,4 \%$ bayi anemia tersebut menderita anemia defisiensi besi. Prevalensi anemia defisiensi besi lebih besar pada bayi 8-12 bulan daripada bayi yang lebih muda, yaitu $73,3 \%$.

Kesimpulan: tidak didapatkan hubungan bermakna antara anemia defisiensi pada bayi dengan jenis kelamin, umur, tingkat pendapatan orang tua, usia gestasi, berat lahir, pemberian ASI ekslusif, susu formula yang difortifikasi besi, dan makanan pendamping ASI, serta infeksi yang diderita bayi.
\end{abstract}

Kata kunci : Anemia, bayi, faktor-faktor

\footnotetext{
Alamat korespondensi:

Dr. Rini Sekartini, Sp.A.

Divisi Tumbuh Kembang Pediatri Sosial. Departemen Ilmu Kesehatan Anak FKUI-RSCM.

Jl. Salemba no. 6, Jakarta 10430.

Telepon: 021-3160622. Fax.021-3913982.

*Rini Sekartini, ${ }^{*}$ Soedjatmiko, ${ }^{* *}$ Corry Wawolumaya, *Irene Yuniar, ${ }^{*}$ Rismala Dewi, ${ }^{* * *}$ Nycane, ${ }^{* * *}$ Imam D, ${ }^{* * *}$ Imam N, ${ }^{* * *}$ Adam

*Departemen Ilmu Kesehatan Anak FKUI-RSCM,** Departemen Ilmu Kedokteran Komunitas FKUI, ${ }^{* * *}$ Mahasiswa FKUI
}

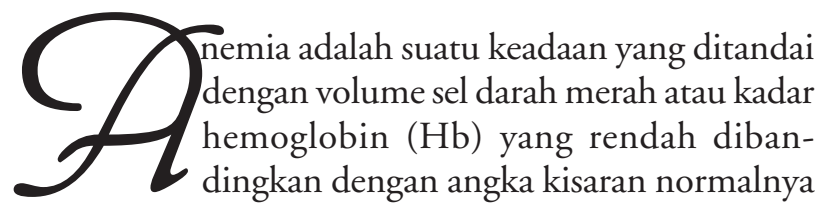
sesuai usia tertentu. ${ }^{1,2}$ Batasan anemia yang ditetapkan World Health Organization untuk bayi usia 6 bulan sampai 6 tahun apabila kadar $\mathrm{Hb} £ 11 \mathrm{~g} / \mathrm{dL}$, nilai ini sesuai dengan kadar hematokrit $(\mathrm{Ht}) 32 \%$ dan nilai volume eritrosit rata-rata (VER) sebesar $72 \mathrm{fL}{ }^{1}$

Anemia defisiensi besi adalah salah satu jenis 
anemia yang paling sering dijumpai di dunia. ${ }^{3}$ Keadaan ini merupakan serangkaian proses yang diawali dengan terjadinya deplesi pada cadangan besi, defisiensi besi dan akhirnya anemia defisiensi besi. Angka kejadian anemia defisiensi besi paling banyak ditemukan pada bayi dan anak. ${ }^{4}$ Pertumbuhan yang cepat, pola makan yang tidak adekuat, infeksi, perdarahan saluran cerna, malabsorpsi, ibu hamil yang mengalami anemia, berat lahir rendah dan usia kelahiran kurang bulan, merupakan penyebab anemia defisiensi besi. ${ }^{4-7}$ Faktor lain yang juga turut berperan adalah jenis makanan, pola asuh, serta budaya dan cara pandang masyarakat terhadap kesehatan ibu dan anak. ${ }^{8}$

Ratnadi dan Soetjiningsih melaporkan angka kejadian anemia defisiensi besi pada bayi yang diberi air susu ibu (ASI) sebesar 18,9\%, bayi usia 4-6 bulan sebesar $6 \%$ dan usia $9-12$ bulan sebesar $65 \% .^{10}$ Sedangkan prevalensi anemia defisiensi besi pada anak usia pra sekolah di Indonesia diperkirakan sebesar 55,5\%. ${ }^{9}$ Hadler dkk, di Brazil, melaporkan prevalensi anemia pada bayi sebesar $60,9 \%$ dan $87 \%$ diantaranya merupakan anemia defisiensi besi. ${ }^{11}$ Pizarro dkk, menemukan angka kejadian defisiensi besi pada bayi yang diberi susu sapi yang tidak difortifikasi dengan zat besi sebesar 20,2\%, sedangkan bayi yang mendapat ASI $4,7 \%$, dan bayi yang mendapat susu formula yang telah difortifikasi dengan zat besi sebesar $0,6 \%{ }^{12}$ Prevalensi anemia di Inggris dilaporkan sebesar $25-40 \%$ pada anak usia 6-24 bulan dengan tingkat sosial ekonomi rendah. Prevalensi ini dikatakan tidak berbeda jauh dengan prevalensi di negara berkembang. ${ }^{13}$

Mengingat oksigenasi sangat diperlukan untuk pertumbuhan otak bayi, anemia defisiensi besi pada bayi dapat berakibat pada perubahan fungsi kognitif, perkembangan motorik, perkembangan mental dan perilaku, serta gangguan psikomotor. ${ }^{11,14,15}$ Melihat besarnya dampak yang ditimbulkan oleh anemia, terutama anemia defisiensi besi, maka tindakan pencegahan, deteksi dini, dan tata laksana yang tepat perlu dilaksanakan. Tujuan penelitian ini adalah untuk mengetahui prevalensi anemia defisiensi besi pada bayi dan faktor-faktor yang mempengaruhinya sehingga dapat dilakukan intervensi yang sesuai.

\section{Bahan dan Cara Kerja}

Penelitian ini merupakan studi cross sectional, dilaksanakan tanggal 29 Maret 2004 sampai dengan
2 April 2004 di Puskesmas Kecamatan Matraman, Puskesmas Kelurahan Utan Kayu Utara, Puskesmas Kelurahan Utan Kayu Selatan II, Puskesmas Kelurahan Pisangan Baru, dan Balai Kesehatan Ibu \& Anak Utan Kayu, Jakarta Timur. Populasi dan subyek penelitian adalah bayi berusia 4-12 bulan sedangkan responden adalah ibu subjek di Kecamatan Matraman Jakarta Timur dan sekitarnya yang berkunjung ke puskesmas tempat penelitian. Pemilihan sampel dilakukan secara haphazard atau convenient sesuai dengan sarana penelitian.

Variabel bebas yang diteliti meliputi jenis kelamin, usia, lingkar kepala, berat badan dan panjang badan bayi, usia ibu, pendidikan ibu, pendapatan per kapita, jumlah anak, masa gestasi, penyakit yang diderita ibu saat hamil, gejala anemia pada kehamilan, kadar $\mathrm{Hb}$ saat hamil, berat lahir, pemberian ASI eksklusif, lama pemberian ASI eksklusif, lama pemberian susu formula, lama pemberian makanan pendamping ASI, riwayat penyakit yang diderita bayi, serta kekerapan bayi menderita penyakit. Variabel terikat pada penelitian adalah anemia defisiensi besi.

Kepada responden diberikan penjelasan mengenai tujuan penelitian dan manfaat penelitian, kemudian responden menandatangani informed consent dan mengisi kuesioner yang dipandu oleh peneliti. Prosedur pemeriksaan $\mathrm{Hb}$ menggunakan Hemocue $^{\circledR}$ menurut prosedur laboratorium SEAMEO-TROPMED sebagai berikut. Pertama mengaktifkan Hemocue $^{\circledR}$, memasukkan pegangan kuvet ke tempatnya, melakukan kalibrasi Hemocue ${ }^{\circledR}$ dengan kuvet standar sebagai kontrol. Fossa cubiti bayi dibersihkan dengan kapas alkohol 70\%, tunggu hingga kering, kemudian ambil darah sebanyak $1 \mathrm{ml}$ dari vena brakhialis. Selanjutnya darah diteteskan ke kuvet steril hingga penuh terisi darah, meletakkan kuvet ke dalam pegangannya, menutupnya, dan tunggu sampai 45 detik, maka kadar $\mathrm{Hb}$ akan terlihat pada layar Hemocue. ${ }^{\circledR}$ Kuvet yang telah dipakai tidak bisa digunakan kembali dan harus dibuang. Batasan anemia bila kadar $\mathrm{Hb}<11 \mathrm{~g} / \mathrm{dL}$, sedangkan anemia defisiensi besi bila kadar $\mathrm{Hb}<11 \mathrm{~g} / \mathrm{dL}$ dan kadar feritin $<12$ ug/L. Bayi yang ditemukan menderita anemia defisiensi besi diberikan suplementasi besi 3-6 mg/ kgBB selama 3 bulan, kemudian dievaluasi kembali dengan pemeriksaan kadar $\mathrm{Hb}$.

Pengolahan data berupa proses editing, verifikasi dan koding. Selanjutnya dilakukan entry data, diolah serta dianalisis dengan uji chi-square dan uji Fischer 
menggunakan program SPSS versi 11.0. Interpretasi data dilakukan secara deskriptif korelatif antara variabel-variabel yang telah ditentukan. Penyajian data dalam bentuk tekstular dan tabular.

\section{Hasil Penelitian}

Dari penelitian diperoleh 55 responden, terdiri dari kelompok usia 4-8 bulan sebanyak 23 bayi $(41,8 \%)$, sisanya 32 bayi $(58,2 \%)$ berusia $8-12$ bulan. Tiga puluh lima $(63,6 \%)$ laki-laki, 96,4\% lahir cukup bulan, dan $85,5 \%$ mempunyai berat lahir antara 2500-4000 gram. Status gizi kurang didapatkan pada $60 \%$ bayi, sedangkan 3,6\% dengan status gizi buruk. Diantara 55 bayi yang diteliti, anemia ditemukan pada 38,2\% dan anemia defisiensi besi $27,3 \%$. Tiga puluh empat $(61,8 \%)$ mendapat ASI eksklusif kurang dari 4 bulan, sedangkan 37 bayi mendapat susu formula yang sudah difortifikasi besi. Empat puluh sembilan bayi $(89,1 \%)$ menderita sakit dalam 3 bulan terakhir, 50,9\% dengan frekuensi 1-4 kali/bulan. Usia ibu terbanyak antara 20-35 tahun (76,4\%), dengan tingkat pendidikan dan ekonomi rendah $43,6 \%$ dan $87,3 \%$. Tiga puluh satu ibu $(56,4 \%)$ menderita anemia selama hamil. Sebaran karakteristik ibu dan bayi tertera pada Tabel 1 .

Umur bayi termuda yang mengalami anemia dan anemia defisiensi besi 4 bulan, kadar $\mathrm{Hb}$ terendah 8,9 $\mathrm{g} / \mathrm{dL}$, dan kadar feritin serum terendah 3,28mg/L. Bayi dengan kadar $\mathrm{Hb}$ terendah berjenis kelamin laki-laki dengan gizi buruk, pendidikan ibu rendah, pendapatan per kapita per bulan sedang dengan jumlah anak dalam keluarga 2 orang, berat lahir dan, usia gestasi normal, ibu mengalami gejala dan tanda anemia saat hamil, bayi mendapatkan ASI ekslusif selama kurang dari 4 bulan, dilanjutkan dengan susu formula yang difortifikasi besi, dan frekuensi sakit kurang dari satu kali per bulan.

Bayi dengan kadar serum feritin terendah adalah bayi laki-laki dengan gizi kurang, pendidikan ibu rendah, pendapatan per kapita per bulan rendah, dan jumlah anak dalam keluarga 8 orang. Bayi memiliki berat lahir normal, usia gestasi normal, ibu tidak mengalami gejala dan tanda anemia selama hamil, bayi mendapatkan ASI ekslusif selama kurang dari 4 bulan, tidak diberi susu formula, frekuensi sakit 1-4 kali/bulan. Hubungan antara karakteristik responden dengan terjadinya anemia defisiensi besi tertera pada Tabel 2 .

\section{Pembahasan}

\section{Karakteristik Bayi}

Pada penelitian ini 3,6\% bayi menderita gizi buruk, dan $60 \%$ gizi kurang. Presentase bayi dengan gizi buruk tidak jauh berbeda dengan karakteristik bayi pada penelitian Survei Kesehatan Nasional 2001 (3,96\%), ${ }^{6}$ namun terdapat perbedaan yang cukup signifikan mengenai sebaran gizi kurang dan gizi lebih. Survey Kesehatan Nasional 2001, mendapatkan frekuensi bayi dengan gizi kurang 7,65\% dan bayi gizi lebih 16,82\%. Hal ini mungkin disebabkan jumlah sampel SKN jauh lebih besar. Survei Kesehatan Nasional 2001 mencatat gizi kurang dan buruk lebih banyak dijumpai pada usia balita yang lebih besar. Hal ini sesuai dengan

Tabel 1. Sebaran karakteristik ibu dan bayi

\begin{tabular}{lcc}
\hline & Rerata $\pm \mathrm{SB}^{*}$ & Median (min-max) \\
\hline Umur ibu (tahun) & $29,91 \pm 6,26$ & \\
Umur bayi (bulan) & $8,02 \pm 2,4$ & \\
Berat badan bayi (kg) & $7,54 \pm 1,21$ & \\
Panjang badan (cm) & $70,01 \pm 3,56$ & \\
Lingkar kepala (cm) & $43,28 \pm 1,74$ & \\
Penghasilan total (rupiah)) & & $850.000(30.000-6.000 .000)$ \\
Jumlah tanggungan (orang) & & $4(3-10)$ \\
Pendapatan perkapita perbulan (rupiah) & & $200.000(10.000-1.000 .000)$ \\
Kadar Hb bayi (g/dl) & $11,51 \pm 1,4$ & $25,02(3,28-95,67)$ \\
Kadar fertin serum (mg/dl) & & \\
* SB : simpang baku & &
\end{tabular}


Sari Pediatri, Vol. 7, No. 1, Juni 2005

Tabel 2. Karakteristik ibu dan bayi berdasarkan kejadian anemia defisiensi besi pada bayi

\begin{tabular}{|c|c|c|c|c|c|c|}
\hline \multirow{3}{*}{ Karakteristik ibu dan bayi } & \multicolumn{4}{|c|}{ Anemia defisiensi besi } & \multirow{3}{*}{$\begin{array}{l}\text { Total } \\
(\mathrm{n}=55)\end{array}$} & \multirow{3}{*}{ Kemaknaan } \\
\hline & \multicolumn{2}{|c|}{$\mathrm{Ya}$} & \multicolumn{2}{|c|}{ Tidak } & & \\
\hline & $\mathrm{n}$ & $\%$ & $\mathrm{n}$ & $\%$ & & \\
\hline \multicolumn{7}{|l|}{ Umur ibu (tahun) } \\
\hline$<35$ & 12 & 27,9 & 31 & 72,09 & 43 & $p>0,05^{a}$ \\
\hline$>35$ & 3 & 25 & 9 & 75 & 12 & \\
\hline \multicolumn{7}{|l|}{ Tingkat pendidikan } \\
\hline Rendah & 6 & 25 & 18 & 75 & 24 & $p>0,05$ \\
\hline Sedang-tinggi & 9 & 29,0 & 22 & 70,9 & 31 & \\
\hline \multicolumn{7}{|l|}{ Pendapatan perkapita } \\
\hline Rendah & 12 & 25 & 36 & 75 & 48 & $p>0,05$ \\
\hline Sedang & 3 & 42,8 & 4 & 57,1 & 7 & \\
\hline \multicolumn{7}{|l|}{ Jenis kelamin } \\
\hline Lelaki & 8 & 22,8 & 27 & 77,1 & 35 & $p>0,05$ \\
\hline Perempuan & 7 & 35 & 13 & 65 & 20 & \\
\hline \multicolumn{7}{|l|}{ Umur bayi (bulan) } \\
\hline $4-8$ & 4 & 17,3 & 19 & 82.6 & 23 & $p>0,05$ \\
\hline$<8-12$ & 11 & 34,3 & 21 & 65.6 & 32 & \\
\hline \multicolumn{7}{|l|}{ Status gizi } \\
\hline Buruk-kurang & 12 & 34,3 & 23 & 65,7 & 35 & $p>0,05$ \\
\hline Normal-lebih & 3 & 15 & 17 & 85 & 20 & \\
\hline \multicolumn{7}{|l|}{ Sakit dalam 3 bulan terakhir } \\
\hline $\mathrm{Ya}$ & 14 & 28,6 & 35 & 71,4 & 49 & $p>0,05^{a}$ \\
\hline Tidak & 1 & 16,7 & 5 & 83,3 & 6 & \\
\hline \multicolumn{7}{|l|}{ Frekuensi sakit (per bulan) } \\
\hline$<1$ & 5 & 19,2 & 21 & 80,8 & 26 & $p>0,05$ \\
\hline $1->4$ & 10 & 34,5 & 19 & 65,5 & 29 & \\
\hline
\end{tabular}

${ }^{a}$ memakai uji kemaknaan Fischer

Tabel 3. Riwayat gestasi dan kelahiran berdasarkan terjadinya anemia defisiensi besi

\begin{tabular}{|c|c|c|c|c|c|c|}
\hline \multirow{3}{*}{ Riwayat gestasi dan kelahiran } & \multicolumn{4}{|c|}{ Anemia defisiensi besi } & \multirow{3}{*}{$\begin{array}{l}\text { Total } \\
(\mathrm{n}=55)\end{array}$} & \multirow{3}{*}{ Kemaknaan } \\
\hline & \multicolumn{2}{|c|}{$\mathrm{Ya}$} & \multicolumn{2}{|c|}{ Tidak } & & \\
\hline & $\mathrm{n}$ & $\%$ & $\mathrm{n}$ & $\%$ & & \\
\hline \multicolumn{7}{|l|}{ Lama mengandung } \\
\hline Cukup bulan & 15 & 28,3 & 38 & 71,7 & 53 & $\mathrm{p}>0,05^{\mathrm{a}}$ \\
\hline Lewat bulan & 0 & 0 & 2 & 100 & 2 & \\
\hline \multicolumn{7}{|l|}{ Sakit selama kehamilan } \\
\hline $\mathrm{Ya}$ & 1 & 16,6 & 5 & 83,4 & 6 & $\mathrm{p}>0,05^{\mathrm{a}}$ \\
\hline Tidak & 14 & 28,6 & 35 & 71,4 & 49 & \\
\hline \multicolumn{7}{|l|}{$\begin{array}{l}\text { Gejala dan tanda anemia } \\
\text { selama kehamilan }\end{array}$} \\
\hline $\mathrm{Ya}$ & 10 & 32,2 & 21 & 67,8 & 31 & $\mathrm{p}>0,05$ \\
\hline Tidak & 5 & 20,8 & 19 & 79,2 & 24 & \\
\hline \multicolumn{7}{|l|}{ Berat bayi saat lahir (gram) } \\
\hline$<2500$ & 2 & 100 & 0 & 0 & 2 & $\mathrm{p}>0,05^{\mathrm{a}}$ \\
\hline$(2500-4000)->4000$ & 13 & 24,5 & 40 & 75,5 & 53 & \\
\hline
\end{tabular}

${ }^{a}$ uji kemaknaan Fischer 
Tabel 4. Asupan makanan pada bayi berdasarkan terjadinya anemia defisiensi besi

\begin{tabular}{|c|c|c|c|c|c|c|}
\hline \multirow{3}{*}{ Asupan makanan bayi } & \multicolumn{4}{|c|}{ Anemia defisiensi besi } & \multirow{3}{*}{ Total } & \multirow{3}{*}{ Kemaknaan } \\
\hline & \multicolumn{2}{|c|}{ Ya } & \multicolumn{2}{|c|}{ Tidak } & & \\
\hline & $\mathrm{n}$ & $\%$ & $\mathrm{n}$ & $\%$ & & \\
\hline \multicolumn{7}{|c|}{ Lama pemberian ASI eksklusif } \\
\hline (bulan) $n=55$ & 10 & 27 & 24 & 70,5 & 34 & $\mathrm{p}>0,05^{\mathrm{a}}$ \\
\hline$<4$ & 5 & 27,7 & 13 & 72,3 & 18 & \\
\hline $4-6$ & & & & & & \\
\hline \multicolumn{7}{|c|}{ Pemberian susu formula $\mathrm{n}=55$} \\
\hline Ya & 8 & 21,6 & 29 & 78,4 & 37 & $\mathrm{p}>0,05^{\mathrm{a}}$ \\
\hline Tidak & 7 & 38,9 & 10 & 61,1 & 17 & \\
\hline \multicolumn{7}{|c|}{$\begin{array}{l}\text { Lama pemberian susu formula } \\
\text { (bulan) } n=37\end{array}$} \\
\hline$<4-(4-6)$ & 4 & 16,7 & 20 & 83,3 & 24 & $\mathrm{p}>0,05^{\mathrm{a}}$ \\
\hline$>6$ & 4 & 30,7 & 9 & 69,3 & 13 & \\
\hline \multicolumn{7}{|c|}{$\begin{array}{l}\text { Lama pemberian MP-ASI } \\
\text { (bulan) } n=54\end{array}$} \\
\hline$<4$ & 5 & 17,9 & 23 & 82,1 & 28 & $\mathrm{p}>0,05$ \\
\hline$(4-6)->6$ & 10 & 38,5 & 16 & 61,5 & 26 & \\
\hline
\end{tabular}

${ }^{a}$ memakai uji kemaknaan Fischer

karakteristik status gizi bayi pada penelitian ini, status gizi kurang ditemukan lebih banyak pada bayi usia 812 bulan dibandingkan usia 4-8 bulan; sedangkan $60,6 \%$ bayi usia $8-12$ bulan mengalami gizi buruk. Sembilan puluh empat setengah presen bayi mendapat ASI ekslusif, lama pemberian kurang dari 4 bulan sebesar $61,8 \%$, dan tidak ada yang diberi ASI ekslusif lebih dari 6 bulan. Angka ini berbeda dengan laporan Survei Kesehatan Nasional 2001 yang melaporkan $96,5 \%$ balita pernah mendapat ASI, terbanyak pemberian ASI eksklusif pada usia 0-3 bulan. ${ }^{6}$

Prevalensi sakit terbesar adalah ISPA yaitu sebesar 87,3\%. Sedangkan Survei Kesehatan Nasional 2001 mendapatkan prevalensi batuk pada balita sebesar $29 \%{ }^{6}$

\section{Prevalensi Anemia dan Anemia Defisiensi Besi pada Bayi}

Prevalensi anemia pada bayi usia 4-12 bulan dalam penelitian ini 38,2\%; 71,4\% di antaranya adalah anemia defisensi besi. Prevalensi anemia defisiensi besi ini belum bisa dibandingkan dengan data di Indonesia karena data prevalensi anemia defisiensi besi pada bayi usia 4-12 bulan di Indonesia sampai saat ini belum diketahui. Jika dibandingkan dengan hasil penelitian yang dilakukan Hadler dkk ${ }^{10}$ di Brazil tahun 2002 ternyata terdapat perbedaan yang cukup signifikan namun lebih mendekati prevalensi anemia di Inggris yang dilaporkan oleh Pizarro dkk. Hadler dkk menemukan prevalensi anemia sebesar 60,9\% dengan 87\% di antaranya merupakan anemia defisiensi besi sedangkan Pizarro $\mathrm{dkk}^{12}$ melaporkan prevalensi anemia sebesar $25-40 \%$ pada anak usia 6-24 bulan. Pizarro dkk juga melaporkan bahwa prevalensi ini tidak berbeda jauh dengan prevalensi di negara berkembang.

Survei Kesehatan Nasional $2001^{6}$ melaporkan prevalensi anemia pada bayi kurang dari 1 tahun lebih dari 60\%, yang berbeda dengan penelitian ini. Perbedaan hasil yang mungkin terjadi karena perbedaan teknik pemilihan sampel, metode pemeriksaan kadar $\mathrm{Hb}$, dan kadar feritin serum. Pada penelitian ini didapatkan prevalensi anemia defisiensi besi pada bayi yang mendapatkan ASI 26,92\%. Angka ini lebih tinggi dengan yang didapatkan Soetjiningsih $\mathrm{dkk}^{9}$ pada penelitian tahun 2001 sebesar 18,9\%. Maka perlu ditindaklanjuti dengan pelatihan dan edukasi pada ibu untuk memberikan makanan pendamping ASI yang mengandung bahan makanan berunsur besi tinggi. 
Sari Pediatri, Vol. 7, No. 1, Juni 2005

\section{Distribusi Anemia Defisiensi Besi menurut Usia Bayi}

Pada penelitian ini juga didapatkan prevalensii anemia defisiensi besi yang lebih besar pada bayi usia 8-12 bulan $(73,3 \%)$, dibandingkan dengan $26,7 \%$ pada bayi usia 4-8 bulan. Hasil ini sejalan dengan anjuran The Commitee on Nurition of the American Academy of Pediatrics $^{3}$ yang menganjurkan uji tapis dilakukan 1 kali antara usia 9-12 bulan dan diulang kembali 6 bulan setelahnya pada populasi yang memiliki prevalensi anemia defisiensi besi yang cukup tinggi, seperti pada penelitian ini. Pada bayi prematur, uji tapis dimulai sejak usia 6-9 bulan. Pada populasi yang memiliki prevalensi anemia yang rendah maka uji tapis dilakukan pada interval usia yang sama. Uji tapis ini dilakukan pada anak-anak yang berisiko tinggi mengalami anemia defisiensi, misalnya bayi yang mendapat ASI eksklusif dan bayi yang lahir dari ibu anemia.

Beberapa penelitian menunjukkan bahwa perubahan yang telah terjadi tidak dapat kembali normal walaupun keadaan anemia defisiensi besi telah teratasi. Hal ini menunjukkan bahwa anemia defisiensi besi yang terjadi pada fase kritis pertumbuhan dan perkembangan otak menimbulkan kelainan permanen. ${ }^{11,16}$ Sebuah follow up study yang dilakukan Puslitbang Gizi Bogor menunjukkan IQ anak yang mengalami anemia lebih rendah 11,34 poin dari anak yang tidak menderita anemia. Penelitian di beberapa negara juga menunjukkan derajat defisit IQ yang bervariasi, tetapi sedikitnya ada defisit sekitar 15 poin IQ. ${ }^{17}$ Soesmaliah dkk melaporkan perubahan proses kognitif yang berhubungan dengan daya konsentrasi visual dan proses belajar pada anak dengan anemia defisiensi besi. ${ }^{18}$ Sherrif dkk melaporkan penurunan skor lokomotor anak usai 18 bulan yang mengalami anemia defisiensi besi sejak usia 8 bulan. ${ }^{19}$

\section{Hubungan antara Karakteristik Responden dengan Prevalensi Anemia Defisiensi Besi pada Bayi}

Pada penelitian ini ternyata tidak didapatkan hubungan yang bermakna antara faktor-faktor yang diduga menyebabkan terjadinya anemia defisiensi besi pada bayi dengan prevalensi terjadinya anemia defisiensi besi pada bayi. Namun dari tabel hasil penelitian dapat dideskripsikan beberapa hal seperti bayi dengan berat lahir < 2500 gram semuanya mengalami anemia defisiensi besi, dan bayi dengan status gizi buruk dan kurang lebih dari sepertiganya mengalami anemia defisiensi besi.

Beberapa penelitian menemukan kemaknaan hubungan antara asupan makanan, tingkat pendapatan dengan prevalensi anemia defisiensi besi pada bayi. Pizarro $\mathrm{dkk}^{12}$ yang melaporkan adanya defisiensi besi pada bayi dengan asupan susu sapi yang tidak difortifikasi dengan zat besi sebesar 20,2\%, pada bayi yang mendapat ASI 4,7\%, dan bayi yang mendapat susu formula yang telah difortifikasi dengan zat besi sebesar $0,6 \%$. Pizarro dkk. juga melaporkan prevalensi anemia defisiensi besi sebesar 25-40\% pada anak usia 6-24 bulan dari keluarga dengan tingkat ekonomi lemah. Hal ini mengidentifikasikan perlunya perhatian atau evaluasi kembali pemberian sirup besi untuk bayi, selain program pemberian tablet besi pada ibu hamil dan melahirkan. ${ }^{20}$ Selain itu Wharf $\mathrm{dkk}^{21}$ melaporkan bahwa berat lahir dan berat badan bayi mempengaruhi cadangan besi bayi usia 4 bulan. Jenis dan komposisi makanan yang dikonsumsi serta jenis kelamin sangat berperan pada cadangan besi bayi usia 8 bulan, sedangkan pada usia 12-18 bulan, dipengaruhi oleh jenis kelamin dan asupan zat besi nonheme.

Pencegahan anemia defisiensi atau defisiensi besi pada masa bayi memegang peran penting terhadap terjadinya dampak jangka panjang. Pencegahan yang bisa dilakukan mencakup pencegahan primer dan sekunder. Pencegahan primer meliputi konseling di pusat-pusat kesehatan mengenai asupan zat besi yang adekuat dan memberikan suplementasi zat besi serta fortifikasi zat besi dalam makanan. Pencegahan sekunder mencakup uji tapis dan diagnosis dini serta tata laksana yang tepat terhadap defisiensi zat besi. ${ }^{20}$ Iriyogen $\mathrm{dkk}^{22}$ melaporkan bahwa pemberian suplementasi zat besi pada anak-anak yang telah mendapat susu formula yang telah difortifikasi sejak usia 6 bulan tidak berbeda bermakna dalam meningkatkan kadar hemoglobin dibandingkan kelompok plasebo, sehingga pada kelompok ini lebih dianjurkan uji tapis pada usia 15-18 bulan.

\section{Kesimpulan dan Saran}

Prevalensi anemia defisiensi besi pada bayi usia 4-12 bulan di Kecamatan Matraman dan sekitarnya 27,3\%. Distribusi anemia defisiensi besi berdasar usia bayi 
didapatkan $26,7 \%$ pada usia $4-8$ bulan dan $73,3 \%$ pada usia 8-12 bulan. Tidak didapatkan hubungan yang bermakna secara statistik antara faktor-faktor yang diduga menyebabkan terjadinya anemia defisiensi besi pada bayi dengan prevalensi terjadinya anemia defisiensi besi pada bayi pada penelitian ini. Namun didapatkan bahwa bayi dengan berat lahir $<2500$ gram semuanya mengalami anemia defisiensi besi, dan bayi dengan status gizi buruk dan kurang lebih dari sepertiganya mengalami anemia defisiensi besi. The Commitee on Nurition of the American Academy of Pediatrics juga menganjurkan uji tapis dilakukan 1 kali antara usia 9-12 bulan dan diulang kembali 6 bulan setelahnya pada populasi yang memiliki prevalensii anemia defisiensi besi yang cukup tinggi, seperti pada penelitian ini.

\section{Daftar Pustaka}

1. The Report of British Nutritional Foundation's Task Force. Iron Nutritional and Physiological Significance. London: Chapman \& Hall 1983. h.1423-58.

2. Glader B. Physiologic anemia of Infancy. Dalam: Behrman RE, Kliegman RM, Nelson WE, Vaughan VC, penyunting. Nelson Textbook of Pediatric edisi ke-17. Philadelphia: W.B Saunders Co 2004. h. 1610.

3. Wu AC, Lesperance LE, Bernstein H. Screening for iron deficiency. Pediatr Rev 2002; 23:71-8.

4. Allen L, Casterline-Sabel. Prevalence and causes of nutritional anemias. Dalam. Ramakhrishnan U. penyunting. Nutritional Anemias. Boca raton: CRC Press 2001. h. 7123.

5. Setianingsih I. Anemia defisiensi besi dan prestasi. Dalam: Wahidiyat I, Gatot D, Mangunatmaja I, penyunting. Perkembangan mutakhir penyakit hematologi onkologi anak. Naskah Lengkap Pendidikan Tambahan Berkala Ilmu Kesehatan Anak XXIV. Jakarta: Balai Penerbit FKUI; 1991. h. 79-95.

6. Tim Surkesnas. Survey Kesehatan Nasional 2001. Laporan SKRT 2001: Studi Kesehatan Ibu dan Anak. Badan Penelitian dan Pengembangan Kesehatan Depkes RI.2001. h. 32-4

7. Tim Surkesnas. Survey Kesehatan Nasional 2001.Laporan SKRT 2001: Studi Kesehatan Ibu dan Anak. Badan Penelitian dan Pengembangan Kesehatan Depkes RI.2001. h. 3

8. Muhilal, Suwarno I, Komari. Review of surveys and supplementation studies of anemia in indonesia. Didapat dari http: //www.unu.edu/ unupress/ food/ 8F171e/ 8F171E03.htm.tanggal 12 Maret 2004

9. Ratnadi IGAA, Soetjiningsih. Iron Status in breast-fed infants.Paediatr Indones 2001; 41:191-6.

10. Walter T, De Andraca I, Chadud P, Perales CG. Iron deficiency anemia:Adverse effects on infant psychomotor development.Arch Dis Child 1989; 84:7-17.

11. Hadler MCCM, Julianto Y, Sigulem DM. Anemia in infancy :Etiology and prevalence. J Pediatr 2002; 78:3216.

12. Pizarro F, Yip R, Dallman PR, et al.Iron status with different infant feeding regimens:Relevance to screening and prevention of iron deficiency. J.Pediatr 1991; 118:687-92.

13. Booth IW, Aukett MA.Iron Deficiency anemia in infancy and early childhood.Arch Dis Child 1997; 76:54954.

14. Walter T, Kovalys J, Stekel A. Effect of mild iron deficiency on infant mental development scores. J Pediatr 1983; 104:519-22.

15. Oski FA, Honig AS. The effects of theraphy on the development scores of iron deficiency infants. J Pediatr 1978; 92:21-5.

16. Lozoff B, Jimenez E, Hagen J,Mollen E, Wolf AW. Poorer behavioral and developmental outcome more than 10 years after treatment for iron deficiency in infancy. Pediatrics 2000; 105:1-11

17. Czajka-Narins DM. Minerals. Dalam : Food, Nutrition \& Diet Therapy. Philadelphia : WB Saunders Company 1992. h. 123-6.

18. Soewondo S, Husaini M, Pollitt E. effect of iron deficiency on attention and learning process in preschool children: Bandung, Indonesia. Am J Clin Nutr 1989; 50:667-74.

19. Sherriff A, Emond A, Bell C, Golding J. Should infants be screened for anemia? A prospective study investigating the relation between haemoglobin at 8,12 , and 18 months and development at 18 months. Arch Dis Child 2001; 84:480-5.

20. Commitee on Nutrition. Iron supplementation for infants. Pediatrics 1976; 68:765-8.

21. Wharf SG, Fox TE, Fairweather-Tait SJ, Cook JD. Factors affecting iron stores in infants 4-18 months of age. Eur J Clin Nutr 1997; 51:504-9.

22. Irigoyen M, Davidson LL, Carriero D, Seaman C. Randomize, placebo controlled trial of iron supplementation in infants with low hemoglobin levels fed iron-fortified formula. Pediatrics 1991; 88:320-6 